\title{
$\mathrm{Zr}_{50} \mathrm{Cu}_{40} \mathrm{Al}_{10}$ 過冷却合金組成のインサート金属䇴積層材を用いた SUS304 板材/CP-Ti 板材抵抗スポット溶接 ${ }^{\prime}$
}

青木 拓也* 山本 篤史郎**

\section{Resistance Spot Welding of SUS304/CP-Ti Plates Using Inserted Stacking Metal Foils with $\mathrm{Zr}_{50} \mathrm{Cu}_{40} \mathrm{Al}_{10}$ Supercooling Alloy Composition}

by

Takuya Аокı* and Tokujiro ҮАмамото**

\begin{abstract}
Dissimilar metallic joining was performed by resistance spot welding of SUS304/CP-Ti plates, where stacking of $\mathrm{Zr}, \mathrm{Cu}$ and $\mathrm{Al}$ foils with $\mathrm{Zr}_{50} \mathrm{Cu}_{40} \mathrm{Al}_{10}$ supercooling alloy composition were placed between the plates as inserted materials. The microstructure in nuggets depends on the stacking sequence of the inserted foils. The size of cavity formed in the nuggets was smallest, no cracks were found in the nuggets and the welding boundary between the nugget and the SUS304 plate was undulated finely for the welded specimen exhibiting the highest tensile shear strength. No metallic glassy phase was found in the nuggets, but the composition of crystalline phase formed in the nuggets was close to high glass-forming alloy, i.e. high supercooling alloy, $\mathrm{Zr}_{50} \mathrm{Cu}_{40} \mathrm{Al}_{10}$.
\end{abstract}

\section{Key words:}

Dissimilar welding, Insert materials, Supercooling, Metallic glasses

\section{1 緒言}

航空機，鉄道，自動車など輸送機器の運用に必要な燃 料とそれに伴い発生する二酸化炭素排出量の低減に有効 な手段として，金属構造材料を適材適所に用いるマルチ マテリアル化が注目されている. マルチマテリアル化で は異なる種類の材料を組み合わせることが不可欠である ため, 異種金属接合はその重要性がかつて無いほど増大 している.

ところが，鋼とアルミニウム合金のような典型的な組 み合わせであっても，特定の条件に最適化した場合など を除けば，汎用的な異種金属接合は困難なことが多い． 代表的な理由として，第一に，接合を高温で行った後に 室温に冷却される過程で発生する熱応力により接合部が 破壊する例が挙げられる ${ }^{1)}$. 第二の理由は, 接合により異 種金属が混合された際に，脆性な金属間化合物相が生じ てクラックが生じることがある点である ${ }^{2), 3) .}$

これらの問題の解決策のひとつが，接合部にインサー 卜材を用いる方法である。これまでに，接合する母材の 種類の組み合わせや接合方法に応じて様々なインサート 材が提案されている ${ }^{4)}$. しかし，母材によって用いるイン サート材が異なることから, 従来とは異なる組み合わせ の母材を異種金属接合する場合，新たにインサート材を 探索する必要がある。これには膨大な時間と経験が求め られるため,これまで異種金属接合の普及を妨げてきた
要因のひとつとなっている.

そこで，接合部を過冷却合金化するようなインサート 材を用いれば，母材に関わらず多種多様な異種金属接合 に適用できる可能性がある，接合部が一般的な合金の場 合, 接合後に冷却が始まると直ちに結晶化するため, 結 晶化温度と室温との温度差が大きい. 接合母材の形状変 化を考慮しなければ, 熱応力はその温度差に比例するた め, 熱応力を抑制するためには, 結晶化温度を低下寸れ ばよい，したがって，接合界面の結晶化温度を下げるた めには接合界面を過冷却合金化することが効果的である. 抵抗スポット溶接では, アーク溶接と比較して接合界面 に局所的に生じる熱は少量であり, かつ, 接合界面が母 材によって迅速に冷却されるため, 接合界面が急冷され る可能性は十分にある.

過冷却能が高いことが知られている $\mathrm{Zr}-\mathrm{Cu}-\mathrm{Al}$ 三元系合 金は共晶温度が低いため，接合界面の組成をその共晶組 成に近づければ結晶化温度を大幅に低下できると期待さ れる。また，接合部が高い過冷却能を有する場合，接合 界面に非平衡相が生じることがあり，接合界面に脆い金 属間化合物相ではなく, 高強度の金属ガラス相や高エン トロピー合金などの非平衡高強度相が生じる可能性もあ る. 異種金属接合では接合部だけでなく，接合部と母材 の界面も重要であるが，過冷却能は三元系以上の合金で 特に高いことから，インサート材に過冷却合金を用いる

$\dagger$ 原稿受理 平成30年8月9日 Received Aug. 9, 2018 C2019 The Society of Materials Science, Japan

* 宇都宮大学大学院工学研究科 $\overline{7} 321-8585$ 宇都宮市陽東

Graduate Student, Utsunomiya University, Yoto, Utsunomiya 321-8585.

** 正 会 員 宇都宮大学学術院 干321-8585 宇都宮市陽東

Academic Association, Utsunomiya University, Yoto, Utsunomiya 321-8585. 
ことは接合部に様々な種類の元素が含まれることを意味 しており，急冷中の限られた時間内に接合部と母材の界 面で原子が相互拡散して十分な接合強度を示すことが期 待される.

抵抗スポット溶接は汎用性が高いため，接合部を過冷 却合金化することにより様々な異種金属接合が可能とな れば，その応用が進むと期待される，そこで本研究では，

SUS304 と CP-Ti の板材を抵抗スポット溶接で接合する際 に，過冷却能の高い $\mathrm{Zr}-\mathrm{Cu}-\mathrm{Al}$ 三元系合金を形成するよう に $\mathrm{Zr}, \mathrm{Cu} ， \mathrm{Al}$ の金属䈃を積層したものをインサート材と して用いて，その接合強度と接合部の微細組織について 調查した.

\section{2 実験方法}

厚さ $1 \mathrm{~mm}$, 長さ $20 \mathrm{~mm}$, 幅 $8 \mathrm{~mm}$ の SUS304 板材と CP-Ti 板材を抵抗スポット溶接で接合した。接合の際はSUS304 板材と CP-Ti 板材の間にインサート材として, 厚さ 0.05 $\mathrm{mm}$ の $\mathrm{Zr}$ 箔材を 3 枚, $0.01 \mathrm{~mm}$ の $\mathrm{Cu}$ 䇴材を 6 枚, $0.011 \mathrm{~mm}$ の $\mathrm{Al}$ 䇴材を 2 枚，それぞれ積層したものを挿入した。 こ の䇴材の組み合わせは, 同じ面積の箔材が溶解した際に 合金組成が $\mathrm{Zr}_{50.2} \mathrm{Cu}_{39.5} \mathrm{Al}_{10.3}$ となるように決定した。これ は過冷却能が高いことで知られる $\mathrm{Zr}_{50} \mathrm{Cu}_{40} \mathrm{Al}_{10}$ 合金とほぼ 同じ組成である. $\mathrm{Fe}$ と $\mathrm{Ti}$ の金属間化合物である $\mathrm{TiFe}_{2}$ 相 と $\mathrm{TiFe}$ 相は融点がそれぞれ $1427^{\circ} \mathrm{C}$ と $1317^{\circ} \mathrm{C}$ である. $\mathrm{Zr}_{50} \mathrm{Cu}_{40} \mathrm{Al}_{10}$ 合金の液相線温度は $827^{\circ} \mathrm{C}$ 以下でガラス転移 温度は $433^{\circ} \mathrm{C}$ と報告されているので ${ }^{5)}, \mathrm{Zr}_{50} \mathrm{Cu}_{40} \mathrm{Al}_{10}$ 合金を インサート材として用いる事で，凝固開始温度が 500〜 $1000 \mathrm{~K}$ 程度低下し得る.よって熱応力を十分抑制できる. また，金属箔の積層順序は Table 1 ならびに Fig. 1 に示す 4 種類とし，それぞれ試料 $\mathrm{P}, \mathrm{Q}, \mathrm{R}, \mathrm{S}$ とした. $\mathrm{Zr}-\mathrm{Al}, \mathrm{Zr}-\mathrm{Cu}$

Table 1 Stacking sequence of inserted metallic foils.

\begin{tabular}{|c|c|}
\hline Specimen & Stacking sequence of inserted metallic foils \\
\hline $\mathrm{P}$ & $\mathrm{SUS} 304$ plate $/ \mathrm{Al} / \mathrm{Zr} / \mathrm{Cu} / \mathrm{Cu} / \mathrm{Zr} / \mathrm{Cu} / \mathrm{Cu} / \mathrm{Zr} / \mathrm{Cu} / \mathrm{Cu} / \mathrm{Al} / \mathrm{Ti}$ plate \\
\hline $\mathrm{Q}$ & $\mathrm{SUS} 304$ plate $/ \mathrm{Cu} / \mathrm{Al} / \mathrm{Zr} / \mathrm{Cu} / \mathrm{Cu} / \mathrm{Zr} / \mathrm{Cu} / \mathrm{Cu} / \mathrm{Zr} / \mathrm{Al} / \mathrm{Cu} / \mathrm{Ti}$ plate \\
\hline $\mathrm{R}$ & $\mathrm{SUS304}$ plate $/ \mathrm{Cu} / \mathrm{Zr} / \mathrm{Cu} / \mathrm{Cu} / \mathrm{Al} / \mathrm{Zr} / \mathrm{Al} / \mathrm{Cu} / \mathrm{Cu} / \mathrm{Zr} / \mathrm{Cu} / \mathrm{Ti}$ plate \\
\hline $\mathrm{S}$ & $\mathrm{SUS} 304$ plate $/ \mathrm{Cu} / \mathrm{Zr} / \mathrm{Al} / \mathrm{Cu} / \mathrm{Cu} / \mathrm{Zr} / \mathrm{Cu} / \mathrm{Cu} / \mathrm{Al} / \mathrm{Zr} / \mathrm{Cu} / \mathrm{Ti}$ plate \\
\hline $\mathrm{T}$ & SUS304 plate $/ \mathrm{Ti}$ plate $($ without inserted metallic foils) \\
\hline
\end{tabular}
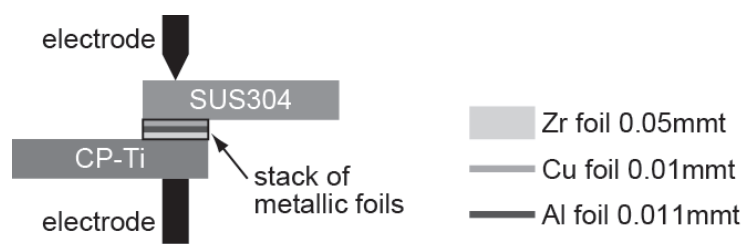

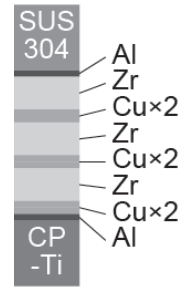

$\mathrm{P}$

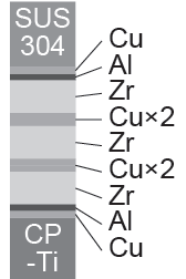

Q

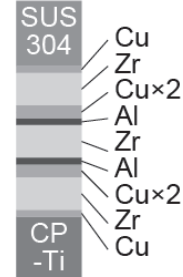

$R$

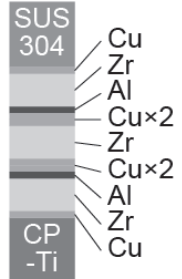

$\mathrm{S}$
Fig. 1 Schematic illustration of spot welding and stacking sequence of inserted metallic foils.

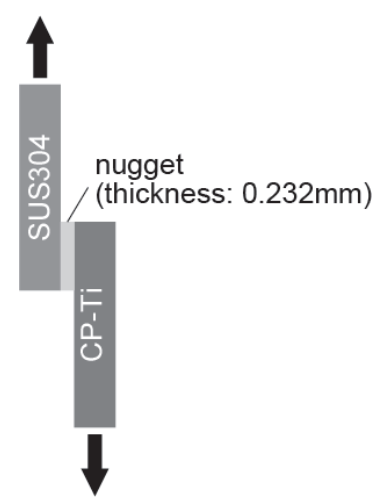

Fig. 2 Spot-welded specimens for tensile shear tests.

の元素の組み合わせは混合エンタルピーの負の絶対值が 大きく, 混合時に大量の熱を発生することが知られてい $3^{6), 7)}$. そこで, 接合時に混合熱が発生して溶解しやすい 䇴材の積層順序を選択した. なお, $\mathrm{Zr}_{50} \mathrm{Cu}_{40} \mathrm{Al}_{10}$ 合金組成 では金属ガラス薄帯を作製可能であるのでインサート材 として用いることも可能である. しかし, 接合では母材 とインサート材の間で原子が拡散することが重要である ため, 本研究では拡散に必要な熱が生じるよう, 純金属 箔の積層材を用いた。

抵抗スポット溶接は市販のポータブル溶接機（大同興 業 ART-7902）を用いて行った. 溶接電流は 390A, 溶接時 間は $0.25 \mathrm{~s}$, 圧力は $600 \mathrm{~N}$ であった。比較のため, 同じ溶 接条件で，インサート金属箔積層材を用いずに接合した 試料 $\mathrm{T}$ も作製した.

接合した試料の接合強度を評価するため，インストロ ン型試験機で引張速度 $0.0167 \mathrm{~mm} \mathrm{~s}^{-1}$ で引張せん断試験を 行った (Fig. 2). 母材厚さが $1 \mathrm{~mm}$, その間に挿入した金 属箔積層材の厚さが $0.232 \mathrm{~mm}$ で薄いため, 引張試験のチ ヤックに試料を取り付ける際にスペーサーを用いなかっ た. すべての試料が接合部で破断したため，その円状の 痕跡から接合部の面積を見積もって最大せん断応力を算 出した。

接合した試料を樹脂中に埋め込んで，おおむね接合部 中央付近の断面が観察できるように試料切断ならびに機 械研磨を行った。接合部の断面組織を走査電子顕微鏡

(SEM) の組成像で観察した。 また, 組成分析を波長分 散型の電子プローブマイクロアナライザー（EPMA）で, 相の同定をX 線回折実験（XRD）で，それぞれ行った。 $\mathrm{XRD}$ には $\mathrm{Cu} \mathrm{K \alpha}$ 線を用い, 組成分析は 5 点の平均值を示 した.

さらに, 断面組織観察結果に関連して, Fe 粉末と $\mathrm{Al}$ 粉末をそれぞれ $10 \mathrm{mg}$ ずつ混合した試料, $\mathrm{Ti}$ 粉末と $\mathrm{Al}$ 粉 末を $10 \mathrm{mg}$ ずつ混合した試料について示差熱分析 (DTA) を $0.67 \mathrm{~K} / \mathrm{s}$ の昇温速度で行い, $\mathrm{Fe}$ と $\mathrm{Al}, \mathrm{Ti}$ と $\mathrm{Al}$ が反応開 始する温度を測定した. 


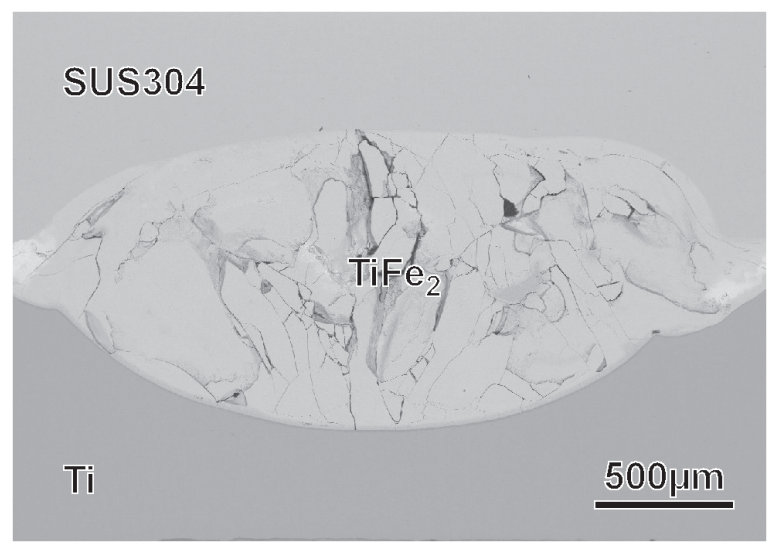

Fig. 3 SEM cross sectional microstructure of the nugget at the boundary of the spot-welded SUS304 and CP-Ti plates in specimen $\mathrm{T}$, where a stack of metallic foils was not inserted.

金属䇴積層材を母材間に挿入せずに抵抗スポット溶接 を行った試料 T の接合部の断面組織写真を Fig. 3 に示す. 接合部に $\mathrm{TiFe}_{2}$ 金属間化合物相が生じ，その内部には多数 のクラックが発生した. Ti-Fe二元系合金は 70at.\%Ti 付近 の共晶組成近傍でアモルファス形成能を有するが限定的 であり ${ }^{8)}$ ，また，Ti，Fe を含む三元系合金では代表的な金 属ガラス・アモルファス合金が存在しないため，接合部 を過冷却化するためにはガラス形成能の高いインサート 材が必要である。

次に,インサート材に金属箔積層材を用いて抵抗スポ ット溶接を行った試料 P， Q， R，S の接合部の断面組織 写真と，試料中に観察された主な領域 A〜I の組成をそれ
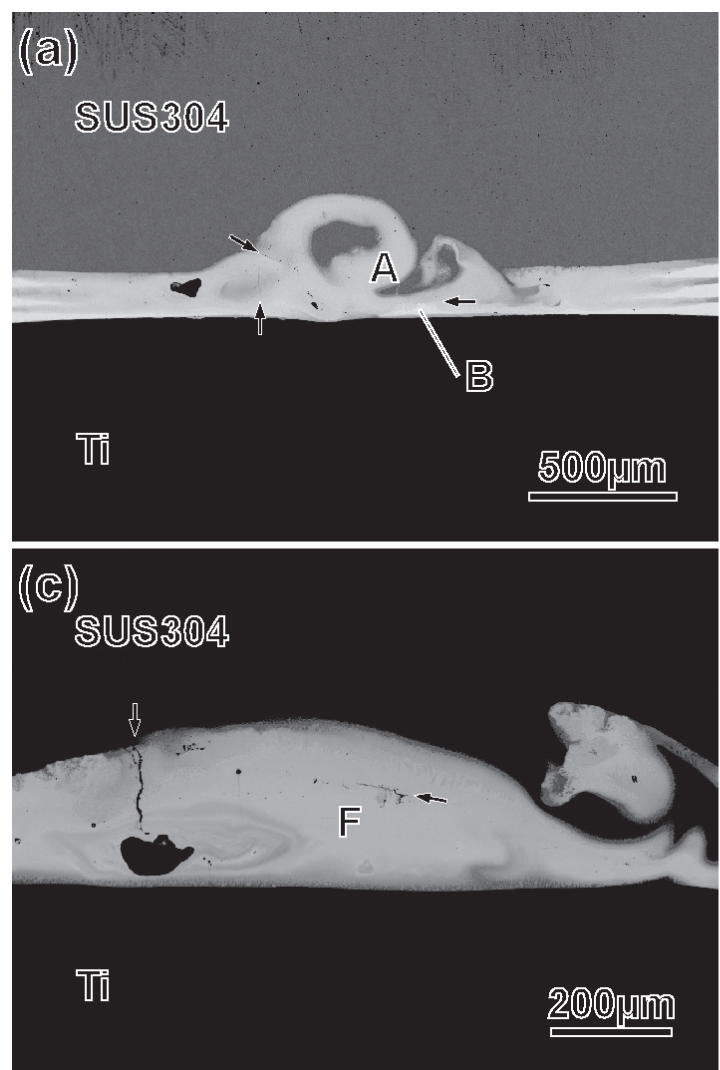

\section{(b)}

SUS304

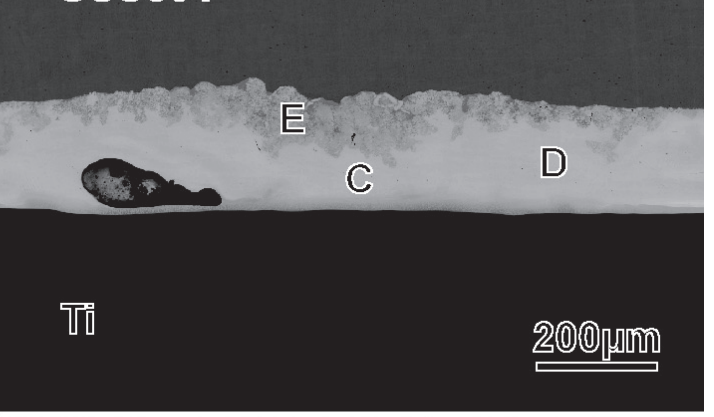

(d)

SUS304

G

$\mathrm{H}$

Ti

Fig. 4 SEM cross sectional microstructures of the nuggets at the boundary of the spot-welded SUS304 and CP-Ti plates with inserted metallic foils in specimen $\mathrm{P}, \mathrm{Q}, \mathrm{R}$, and $\mathrm{S}$. 


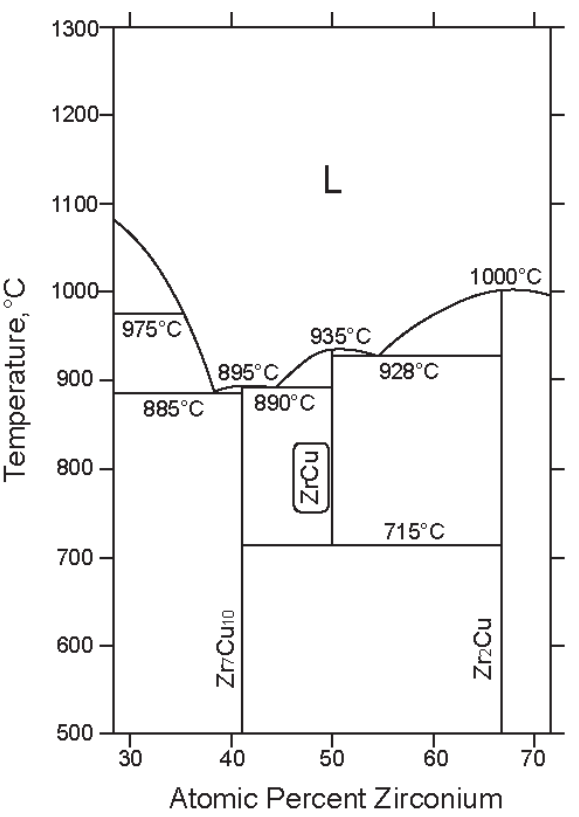

Fig. $5 \mathrm{Zr}-\mathrm{Cu}$ binary alloy phase diagram in the vicinity of the $\mathrm{ZrCu} \mathrm{B} 2$ phase $^{7)}$.

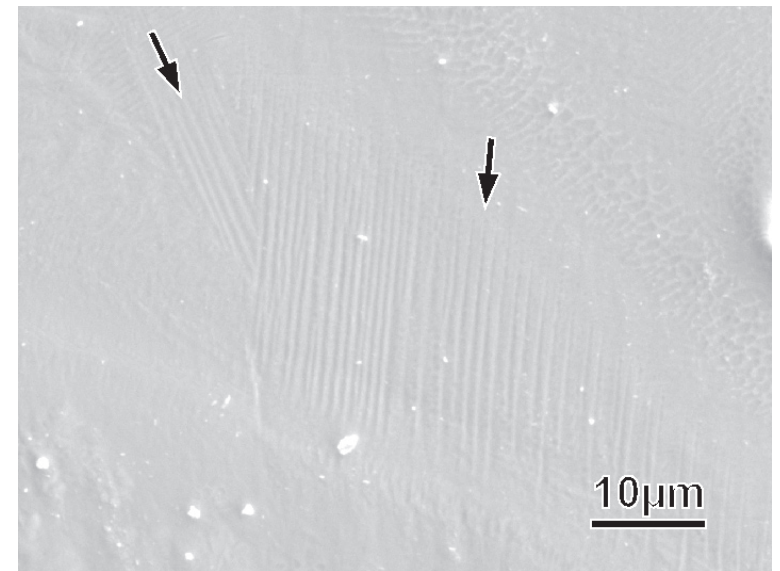

Fig. 6 High magnification SEM backscattering electron image in region A in Fig. 4(a). Arrows indicate martensite relief.

ら $\mathrm{Zr}_{7} \mathrm{Cu}_{10}$ 相と $\mathrm{Zr}_{2} \mathrm{Cu}$ 相に拡散変態する ${ }^{9)}$.この $\mathrm{ZrCu}$ 相は 急冷により B2 相から B19'相にマルテンサイト変態を生じ ることが知られている ${ }^{10), 11)}$. 試料 P においても SEM 像を 注意深く観察すると，領域 A で Fig. 6 に示すようにマル テンサイト変態により生じた起伏が観察された。 なお, マルテンサイト変態は無拡散変態なので, 組成像ではマ ルテンサイトバリアントはコントラスト差を生じないは ずであるが，本試料ではたまたま結晶方位差や表面起伏 により反射電子強度に差が生じたものと考えられる. 中 間層 $\mathrm{ZrCu}$ 相が $\mathrm{Zr}_{7} \mathrm{Cu}_{10}$ 相と $\mathrm{Zr}_{2} \mathrm{Cu}$ 相の平衡相に拡散変態 せずに，マルテンサイト変態を生じたことから，接合界 面は確かに急冷されていることがわかった。

Fig. 7(a)に試料 P の接合部断面全体の XRD パターンを 示す. 母材である SUS304 板材と CP-Ti 板材の他に, イン サート積層材に用いた $\mathrm{Zr}$ 箔と $\mathrm{Cu}$ 䈃の回折ピークが観察 された。しかし，接合部に生じた金属間化合物相は，回 折ピークを生じるほど含まれていなかった。また，金属 ガラス相の存在を示寸ハローも XRD パターンには観察さ
れなかった. $\mathrm{ZrCu}$ や $\mathrm{Zr}_{2} \mathrm{Cu}$ などの金属間化合物相のピー クが検出されると期待される 40 度付近の回折角付近につ いて接合部の微小部 XRD 実験も行ったが, Fig. 7(b)に示 す通り母材とインサート䇴材のほかに，新たに接合によ って生じた相の回折ピークは観察されなかった。試料中 に閉める接合部の割合を考慮すると同様の結果が予想さ れたため, 本研究ではその他の試料の接合部断面の XRD パターンは測定しなかった。

試料 Q の断面組織写真を Fig. 4(b)に示す. 試料 P と異 なり，接合部は層状であった。接合部には大きな空隙が 観察されたが，クラックは観察されなかった。母材と接 合部の界面は, CP-Ti 側が平滑であったのに対し, SUS304 側は大きな凹凸が観察された。最大せん断応力は 137〜 $331 \mathrm{MPa}$ であり, 試料によって大きな差があった。接合部 で最も広い領域を占める $\mathrm{C}$ と $\mathrm{D}$ はそれぞれ $\mathrm{Zr}_{50} \mathrm{Cu}_{50}$ と $\mathrm{Zr}_{60} \mathrm{Cu}_{40}$ に近いほぼ二元系の組成であり, 過冷却を比較的 生じ易い組成である，接合部の過冷却能が比較的高かっ たことが，本試料の接合部にクラックが生じていない理 由のひとつと考えられる。この試料の接合部と SUS304 板材の界面付近には Fe 4 43at.\%含む領域 E が存在し, 接 合部と SUS304 板材の間で相互拡散を生じたことを示し ている。 また相互拡散で生じた化合物相により, その界 面は凹凸状であった。

試料 R の断面組織写真を Fig. 4(c)に示す. 試料 P と同様 に，接合部では母材とインサート材が立体的に混合して いた．接合部には大きな空隙とクラックが観察された。 母材と接合部の界面はSUS304 側と CP-Ti 側のいずれも平
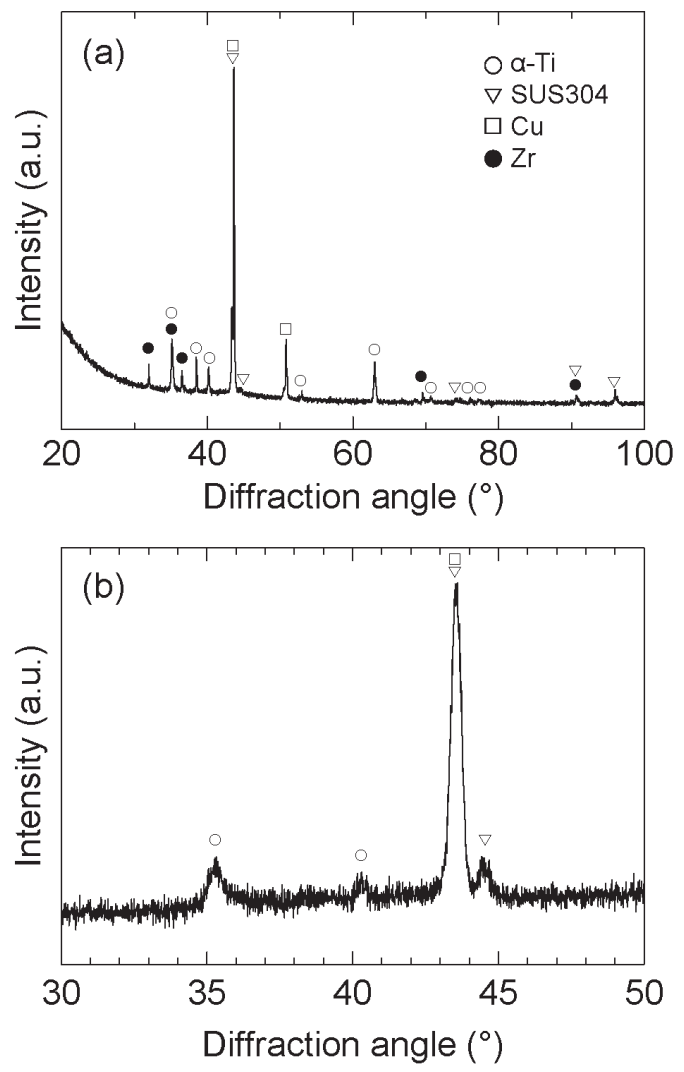

Fig. 7 XRD pattern of the cross section of specimen P. (a) the nugget, plate and inserted foils, and (b) the nugget. 
滑であった. 最大せん断応力は 130 429MPa で, 本研究で 最も高い值と低い值を示した。接合部の大部分は試料 Q と同様に $\mathrm{Zr}_{50} \mathrm{Cu}_{50}$ に近いほぼ二元系の組成であったが, 接 合部に空隙とクラックが生じた.

試料 S の断面組織写真を Fig. 4(d)に示す. 接合部は母材 とほぼ平行な層状であった。接合部にはごく小さい空隙 が観察されるがその数は少なく, クラックは観察されな かった，母材と接合部の界面は，CP-Ti 側は平滑であった が，SUS304 側は細かい波状であった．最大せん断応力は 205 276MPa で, 試料 P, Q, R と比較すると幅が小さか った。接合部には $\mathrm{Zr}_{60} \mathrm{Cu}_{30} \mathrm{Al}_{10}$ に近い三元系組成の領域が あり，本研究で作製した試料中で接合部の過冷度が最も 高かったと考えられる．空隙が少ないこととクラックが 生じなかったことは接合部の合金の高い過冷度と対応し ている. 接合部とSUS304 板材の界面を高倍率で観察した ところ, Fig. 8 に示寸様に, 試料 Q と同様だが細かい凹凸 が生じていた.こうした凹凸界面が SUS304 板材側にのみ 生じた理由の一つとして, Fe と $\mathrm{Ti}$ が溶融した $\mathrm{Al}$ と反応 を開始する温度が考えられる. $\mathrm{Al}$ 粉末と $\mathrm{Fe}$ 粉末の混合試 料と $\mathrm{Al}$ 粉末と $\mathrm{Ti}$ 粉末の混合試料について DTA 測定を行 った結果を Fig. 9 に示す. $\mathrm{Al}$ 粉末と Fe 粉末の混合試料は, $660^{\circ} \mathrm{C}$ で $\mathrm{Al}$ 粉末が融解した後, 直ちに $\mathrm{Al}$ と $\mathrm{Fe}$ 粉末が反 応して発熱を生じた。一方, $\mathrm{Al}$ 粉末と $\mathrm{Ti}$ 粉末の混合試料

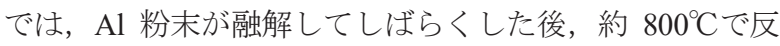
応を開始した，インサート材に用いた元素のうち，Fe な らびに $\mathrm{Ti}$ 中で最も拡散速度が大きい元素が $\mathrm{Al}$ である.し たがって, $\mathrm{Al}$ との反応開始温度が低い $\mathrm{Fe}$ を主成分として 含む SUS304 板材との界面の形状が CP-Ti 板材より先に変 化したと考えられる.

爆着や電磁圧接では接合界面が波状であると高い接合 強度を示すと報告されている ${ }^{12)-15)}$ ，これらの報告では2 種類の母材がかみ合って凹凸状の界面を形成している. 本研究で凹凸を生じた界面は接合部と母材の SUS304 板 材の間のみであるため, 界面の形状が必ずしも接合強度 を向上しなかったと考えられる。

試料 $\mathrm{P}, \mathrm{Q}, \mathrm{R}$ は試料 $\mathrm{S}$ と比べて最大せん断応力に幅が あった。応力集中を生じる空隙やクラックの発生は試料 によって個体差があったためであると考えられる。この 結果は，試料の個体差を少なくするためには，混合熱の 発生に不可欠な $\mathrm{Al}$ 箔を, 混合熱が接合部全体に伝播する よう，インサート金属箔積層材の中央部に配置すること が必要であることを示唆している.

\section{4 まとめ}

SUS304 板材と CP-Ti 板材の抵抗スポット溶接において, その接合界面に過冷却能の高い合金を生じる $\mathrm{Zr}, \mathrm{Cu}, \mathrm{Al}$ からなる金属箔積層材をインサート材として配置し，異 種金属接合が困難である原因の一つである，熱膨張率の 差に起因して生じる残留応力を抑制することを試みた。

接合部の組成が高過冷却能を有する $\mathrm{Zr}_{50} \mathrm{Cu}_{40} \mathrm{Al}_{10}$ となる よう積層した金属䈃をインサート材として用いることに

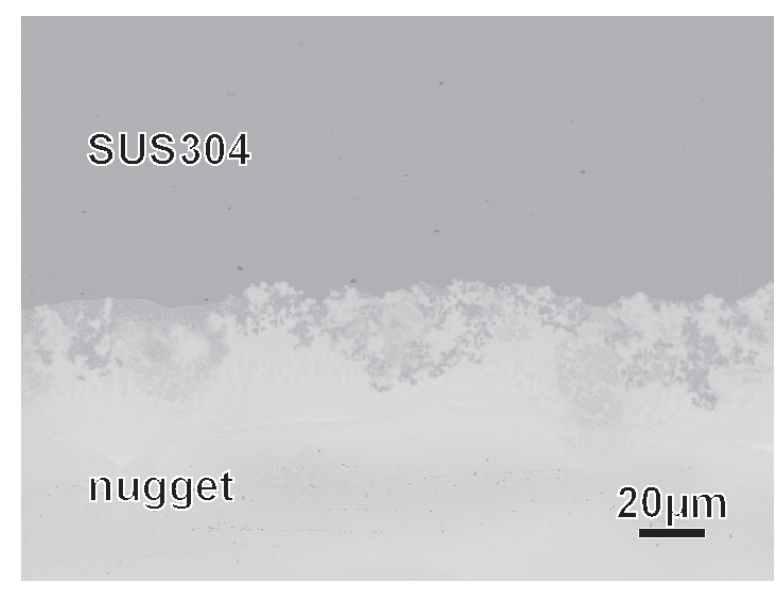

Fig. 8 High magnification SEM backscattering electron image of the boundary between the SUS304 plate and the nugget in Fig. $4(\mathrm{~d})$.

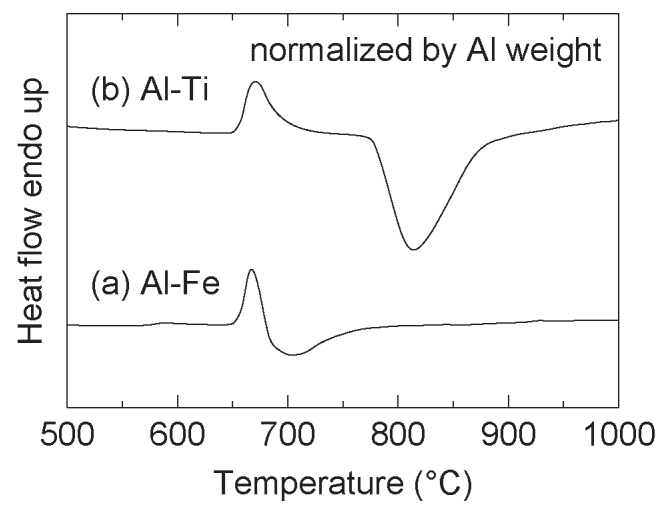

Fig. 9 DTA traces of the mixture of (a) $\mathrm{Al}$ and Fe powder and (b) $\mathrm{Al}$ and Ti powder.

より，接合部に生じるクラックの数を大幅に抑制できた. さらに, 金属箔の積層順序によって, 接合部の空隙生成 も抑制できたほか, 接合部と母材の界面の形状が波状に なるなどの変化が生じた，応力集中を生じる空隙やクラ ックが存在すると接合強度のばらつきが大きくなった.

本研究は, 東北大学金属材料研究所研究部ならびに附 属新素材共同研究開発センターとの共同研究 (課題番号 18K0051，18G0040）により行った. また, 本研究の一部 では, 公益社団法人軽金属奨学会研究補助金ならびに公 益社団法人池谷科学技術振興財団単年度研究助成のご支 援を賜った。

\section{参 考 文 献}

1) E.M. Anawa and A.G. Olabi, "Control of welding residual stress for dissimilar laser welded materials", Journal of Materials Processing Technology, Vol. 204, No. 1-3, pp. $22-33$ (2008).

2) R. Borrisutthekul, T. Yachi, Y. Miyashita and Y. Mutoh, "Suppression of intermetallic reaction layer formation by controlling heat flow in dissimilar joining of steel and aluminum alloy", Materials Science and Engineering A, Vol. 467, No. 1-2, pp. 108-113 (2007).

3) T. Morishige, A. Kawaguchi, M. Tsujikawa, M. Hino, T. Hirata and $\mathrm{K}$. Higashi, "Dissimilar welding of $\mathrm{Al}$ and $\mathrm{Mg}$ alloys by 
FSW", Materials Transactions, Vol. 49, No. 5, pp. 1129-1131 (2008).

4) J.-M. Park, K.-Y. Kim, K.-K. Kim, K. Ito, M. Takahashi and M.-H. Oh, "Effects of insert metal type on interfacial microstructure during dissimilar joining of TiAl alloy to SCM440 by friction welding", Metals and Materials International, Vol. 24, No. 3, pp. 626-632 (2018).

5) Y. Yokoyama, T. Yamasaki, P.K. Liaw and A. Inoue, " Study of the structural relaxation-induced embrittlement of hypoeutectic $\mathrm{Zr}-\mathrm{Cu}-\mathrm{Al}$ ternary bulk glassy alloys ", Acta Materialia, Vol. 56, No. 20, pp. 6097-6108 (2008).

6) A. Takeuchi and A. Inoue, "Classification of bulk metallic glasses by atomic size difference, heat of mixing and period of constituent elements and its application to characterization of the main alloying element", Materials Transactions, Vol. 46, No. 12, pp. 2817-2829 (2005)

7) F.R. Boer and D.G. Perrifor, "Cohesion in metals", (1988) Elsevier Science Publishers B.V.

8) U. Mizutani, Y. Hoshino and Y. Yamada, "Amorphous gokin sakusei no tebiki", pp. 154-155 (1986), AGNE Gijutsu Center.

9) D. Arias and J.P. Abriata, in "Binary alloy phase diagrams, 2nd ed. Vol. 2", Eds. T.B. Massalski, H. Okamoto, P.R. Subramanian and L. Kacprzak, p. 1511 (1990) ASM International.

10) D. Schryvers, G.S. Firstov and A.V. Kotko, "Unit cell determination in $\mathrm{CuZr}$ martensite by electron microscopy and X-ray diffraction", Scripta Materialia, Vol. 36, No. 10, pp. 1119-1125 (1997).

11) J.W. Seo and D. Schryvers, "Defect structures in $\mathrm{CuZr}$ martensite, studies by CTEM and HRTEM", Journal de Physque IV Vol. 7, No. C5 pp. 149-154 (1997).

12) K. Shanthala and T.N. Sreenivasa, "Review on electromagnetic welding of dissimilar materials", Frontiers of Mechanical Engineering, Vol. 11, No. 4, pp. 363-373 (2016).

13) T. Itoi, A.B. Mohamad, R. Suzuki and K. Okagawa, "Microstructure evolution of a dissimilar junction interface between an $\mathrm{Al}$ sheet and a $\mathrm{Ni}$-coated $\mathrm{Cu}$ sheet joined by magnetic pulse welding", Materials Characterization, Vol. 118, pp. 142-148 (2016).

14) R.N. Raoelison, D. Racine, Z. Zhang, N. Buiron, D. Marceau and M. Rachik, "Magnetic pulse welding: Interface of $\mathrm{Al} / \mathrm{Cu}$ joint and investigation of intermetallic formation effect on the weld features", Journal of Manufacturing Processes, Vol. 16, No. 4, pp. 427-434 (2014).

15) K.-J. Lee, S. Kumai, T. Arai and T. Aizawa, "Interfacial microstructure and strength of steel/aluminum alloy lap joint fabricated by magnetic pressure seam welding", Materials Science and Engineering A, Vol. 471, No. 1-2, pp. 95-101 (2007). 